\title{
Between Normative Power and Soft Power: the Psagot case
}

\author{
NELLIE MUNIN \\ Zefat Academic College, Israel \\ nelliemunin@gmail.com \\ OFER SITBON \\ Zefat Academic College, Israel \\ sitbonofer@gmail.com
}

\begin{abstract}
The Psagot judgment, handed down by the European Court of Justice (CJEU) in 2019, provides that products originating in Israeli settlements in territories Israel occupied during regional wars, exported to the EU, should be labelled as such, to allow consumers make an informed political choice. This article argues that the Psagot judgment thus reinforces normative, 'top-down' governmental power with soft, 'bottom-up' consumer power. Psagot's implications for Israel-EU relations is discussed along with the effectiveness of the EU approach in the short and longer terms.
\end{abstract}

Keywords: Psagot, EU, Israel, Normative Power, Consumer Protection, Corporate Responsibility

\section{Introduction}

The Psagot judgment (CJEU, 2019) is the latest link in a long chain of EU measures aimed at excluding the territories occupied by Israel during regional wars (hereafter: 'the territories') from the Israel-EU Association Agreement's scope (European Union, 2000). ${ }^{1}$ The judgment broadly interprets the labelling requirement included in EU Regulation 1169/2011 (European Union, 2011) aimed at consumer protection, to include political and ethical information. Consequently, it provides for the labelling of products originating in Israeli settlements as such. Compared to former EU measures regarding the territories and CJEU's Brita judgment (CJEU, 2010), Psagot judgment marks a partial shift of decision and implementation power from the governmental and institutional 'top-down' sphere to the private 'bottom-up' sphere of individual consumers (Sitbon, 2020). This article examines to what extent CJEU's perception underlying the Psagot judgment is compatible with the Normative Power and Soft Power theories, discussing its implications for Israel-EU relations. It further assesses the effectiveness of this CJEU/EU's approach in the short and the long run.

${ }_{1}^{1}$ This agreement was concluded in 1995 and came into force in 2000. 


\section{Normative Power Europe}

The notion of power is essential to international diplomacy. International players, states, international organizations, multinational corporations ${ }^{2}$, or regional alliances such as the EU, try to change the attitude of other international players, to make them adopt their positions, or positions serving their interests best, sharing their ideas, values, behaviours, and cultures. Nye $(2009,160)$ mentions three basic ways to do this: coercion and payment ('hard power') and attraction ('soft power').

Normative power is a form of soft power, based mainly upon the use of conceptual justifications. It is exercised by the formation, implementation, and enforcement of legal norms. An entity acting as a normative power seeks to project its norms into the international system (De Zutter, 2010). Deviation from these norms might be subject to sanctions.

François Duchêne $(1972,1973)$ suggests that by using progressive civilian power, based on economic, diplomatic, and cultural measures rather than traditional military power, Europe can lead towards peaceful international relations. Some scholars (e.g., Hill, 1993, 318-2; Smith, 2000, 15-9) doubt Duchêne's observation. ${ }^{3}$ The enhancement of European influence over the international order after the formation of the EU triggered the development of the term "Normative Power", which added a cognitive and sociological dimension to the traditional institutional discourse in International Relations. Normative power refers to the EU's ability to exert its ideological influence and to diffuse its laudable values and standards (e.g., Cardwell \& Wessel, 2020, 13-15) across the international community. Sometimes other forms of soft power, such as cultural diffusion, policies, and institutionalized dialogue complement it (Manners, 2002, 235-58).

In light of criticisms regarding the lack of conceptual precision (e.g., Forsberg, 2011), scholars aimed to fine-tune the "Normative Power" theory, viewing it as an analytical ideal type that can be streamlined into two groups: (1) its normative basis and (2) its normative practice. Kienzle (2014) adds another indication: its potential impact. Our analysis will examine these aspects. Menon et al. $(2004,11)$ describe the EU as one of the "most formidable machines for managing differences peacefully ever invented." Manners (2002) contends that the EU's power capacities emanate from its position in the global economy, its population, and broad membership. Maull (2005) stresses its force in international politics, consisting of its economic attraction, political success, and wealth.

In the global arena, the EU shifted from "physical impositions of imperialism" in the past to setting "world standards by normative terms" (Rosecrance, 1998, 22). It strives to establish and preserve its position as "a major normative and civilian power, playing a significant role in the areas of humanitarian aid, environmental sustainability, multilateralism, human rights, and development, among other things." (Davis Cross, 2013, 1). The EU's norm-driven practices aim to enhance an observably distinct behaviour in world politics (Manners, 2002), shaping the will of the power-recipients

\footnotetext{
${ }^{2}$ The realization of increased power exerted by multinational corporations (Strange, 1991) was developed in later literature (E.g. Babic et al., 2017).

3 EU's global political effect was alternatively described as soft imperialism, superpower, civilian power, good citizens Europe and ethical power Europe (De Zutter, 2010).
} 
(Galtung, 1973, 36), simultaneously strengthening the EU's security and comparative advantage in the world economy through this process (De Zutter, 2010).

The "Normative Power Europe" perception has been criticized in several theoretical respects. Neo-realists exposed its utopian and overly immaterial aspect in light of the reality on the ground (Whitman, 2011). Pragmatists argue that the EU's trade policy usually reflects a selective imposition of Normative Power vis-à-vis developing countries, shaped and influenced by pressures of organized groups and their economic interests (Poletti and Sicurelli, 2018). Some describe the "Normative Power Europe" as an empire, emphasizing the unequal power relations which the EU maintains with its neighbours. This approach helps in explaining controversial EU politics concerning authoritarian regimes (Del Sarto, 2016).

Scholars have demonstrated the vital link between the EU's normative power and its international image, enhanced by its use of soft power and ethical positions (e.g. Smith (2006, 22, 27). However, others (e.g., Pace, 2009) question the EU's self-image of promoting democracy in light of its actual practice concerning non-EU Mediterranean countries.

\section{The EU's Normative Power in the Mediterranean Context}

The Venice Declaration (European Commission, 1980) reflects the EU's determination to play a meaningful role in the Mediterranean region, working 'in a more concrete way towards peace' (Art. 2) based on 'principles universally accepted by the international community' (Art. 4). In recent years, this desire has been reinforced by the ongoing stagnation in the peace process between Israel and the Palestinians, the continued expansion of the population in the settlements beyond the pre-1967 borders, and the Israeli conflict management policy associated with it, all of which have increased European frustration. Manners (2002, 244-245) suggests that the EU's normative power is exercised, among other ways, by transference - diffusion taking place when the EU exchanges goods, trade, aid or technical assistance with third parties, including what he calls "carrot and stickism" of financial rewards and economic sanctions.

The EU is Israel's major trading partner. ${ }^{4}$ Israel desires to deepen its integration with the EU. In the EU leadership's eyes, these facts constitute significant leverage over Israeli public opinion, facilitating the exercise of "carrot and sticks" to strengthen and enhance the policy of differentiation between Israel and the territories. ${ }^{5}$ Association agreements serve as legal platforms by which the EU exports its legal norms (Oliviera, 2015, 7). Beginning with the Venice Declaration (European Union, 1980), and even more since the Oslo process in the mid-1990s, the EU has been trying to impose its view on Israel, regarding the Israeli-Palestinian territories' political dispute. The conclusion of the EU-Israel Association Agreement (1995) and EU-PLO Association Agreement (1997) enhanced this process, encouraging the exclusion of goods originating in the Occupied Territories from the former's scope.

\footnotetext{
${ }_{4}^{4}$ Annual trade flows between Israel and the EU in 2019 exceeded 45bn \$, about one third of Israel's entire international trade. For comparison, in 2019 Israel's trade with the US amounted to $27.7 \mathrm{bn} \$$ and with China to 11.2 bn $\$$ (Israeli CBS, 2020).

5 Other possible steps include restricted European cooperation with Israeli banks operating in the settlements; Reducing tax benefits for European organizations which support the settlements; Revocation of the validity of official Israeli documents issued in the Occupied Territories (e.g., on behalf of Ariel University), etc.
} 
During this time, the EU used different soft power techniques to affect Israel's position regarding the regional conflict:

\section{Political Dialogue}

Soft power is about convincing, about getting other countries to want what a country wants. (Nye, 1990; 2004; 2009, 161). A dialogue facilitates 'persuading others,' 'invoking norms' agreed by the parties in mutual agreements, discussing 'what is normal,' and exercising 'the power of example' (Frosberg, 2011, 1196-1198).

Article 3 of the EU-Israel Association Agreement provides for an ongoing political dialogue between its parties. The political dialogue regarding the territories' dispute has had its ups and downs. In the Oslo process (1993-1996), Israel and EU positions were arguably most aligned. Though the Oslo process stuttered in the late 1990s (under the first Netanyahu government), under Barak's government (1999-2001), Israel accepted Clinton Parameters of 2000 (i.e., agreeing to a Palestinian state in most of the Gaza Strip's territory and the West Bank, with a Palestinian capital in East Jerusalem). While Israel's military actions in response to the Second Intifada attracted much EU criticism, in 2003 Israeli PM Sharon's government accepted the EU-backed Roadmap. In 2008, during the Annapolis talks, Israeli PM Olmert proposed a Palestinian state in territories equivalent to $100 \%$ of the Gaza Strip and West Bank. In 2009 even Israeli PM Netanyahu accepted the two-state principle in his Bar Ilan speech. However, his government's positions in recent years have exacerbated the differences between Israel and the EU concerning the territories' status. Furthermore, Israel's continuous settlement construction in the territories has undermined the EU's faith in the Israeli commitment to the two-state solution, arguably rendering this solution considerably less feasible. Consequently, the EU realized that a political dialogue alone would not suffice to change the Israeli position.

\section{The Brita Judgment: From Dialogue to "Top-Down" Legal Action}

The 2010 Brita case marked a deviation from a mere political dialogue between Israel and the EU. It enabled the CJEU to impose the EU's normative power on Israel, using legal interpretation, judgment, and enforcement - embedded within this highlyconflicted political context, implying an economic threat to certain Israeli activities in the territories. This judgment deprived goods originating in the Occupied Territories of the EU-Israel Association Agreement's benefits, contending that they should be covered by the EU-PLO Agreement (CJEU, 2010, paras. 43-53).

This judgment invited criticism (e.g. Pardo and Zemer, 2011, Munin, 2011, 2013) and anger in Israeli public opinion. EU measures that followed it were perceived as sanctions, although the EU stressed that these are not sanctions according to public international law. These measures caused economic losses to Israeli businesses in the territories. Some companies moved their operations into the 1967 borders to avoid them. Nevertheless, Israel's approach towards the territories did not change.

\section{The Psagot Judgment: Combining "Top-Down" and "Bottom-Up" Pressures}

As Brita's strategy did not deliver the desired results, the Psagot judgement marks an EU attempt to reinforce the "top-down" normative power with "bottom-up," "local power" pressure. The growing importance of the "power of local" in international 
diplomacy is broadly acknowledged (e.g. Diez, 2013). Gordon and Pardo (2015) identify its contribution in the context of the Occupied Territories. Such civic activism reinforces the EU's normative power, as individuals and domestic courts in EU member states take advantage of the EU's legal system to promote their agendas, thus strengthening the EU's legal system (De Witte et al., 2016) ${ }^{6}$ circumventing the reluctance of governments to enforce EU law due to political and other considerations.

De Zutter (2010) suggests that normative power consists of four elements: a political entity exercising "power" emanating from its "presence"; others recognize and confirm the normative power and its norms; consequently, an impact on the others is obtained. Forsberg (2009) contends that normative power involves: (1) a normative identity; (2) normative interests; (3) practice according to norms; (4) a normative means of power; and (5) normative ends.

As in Brita, in Psagot a political entity, the EU, exercises "power", using consumer protection regulation to make a political point. It draws on a normative basis: EU law, enshrining EU's normative identity and interests and reinforcing public international law rules. Its implementation forms the normative practice. Psagot judgment reflects and applies the EU's normative means of power (i.e., warning EU consumers that products originating in 'Israeli Settlements' in the territories, thus potentially affecting their consumption), striving towards the normative end of ending the IsraeliPalestinian regional dispute. The open question is whether, or to what extent, other international players will recognize and confirm this move and what impact it might have.

Simultaneously, the Psagot judgment illustrates complementary "local powers" contributions, both in Israel and in the EU, reinforcing the evolving top-down treatment of the territories' dispute between Israel and the EU:

Israeli "local powers" have initiated the Psagot case: i.e., the Psagot winery owners who explicitly declared their aim to challenge France's labelling requirements not only on business grounds but also on political grounds. The Israeli government did not support their initiative. On the contrary: the Israeli Ministry of Foreign Affairs, concerned of the broad potential political consequences of such a judgment, asked them to withdraw their claim, but they refused to do so. They activated France's domestic court, which referred an interpretative question to the CJEU, and applied the latter's interpretation of EU law to the case before it. The French court's reference triggered an interpretation of EU law that was unknown before and is now mandatory in all member states.

The Psagot judgment's interpretation of EU regulation 1169/2011 empowers EU consumers' "local power". By endorsing considerations that take into account bottom-up ethical consumerism, the EU seems to deviate, for the first time in this context, from its conventional top-down approach towards the Israeli-Palestinian issue. This civic bottom-up pressure adds an essential complementary component to the EU's political top-down leverage in the region, broadening the traditional concept that normative power emanates from the academic and political elite (Hopf 1998).

\footnotetext{
${ }^{6}$ A major shortcoming of this method is the limited scope of CJEU discussion, which prevents the formation of an overall, consistent EU approach to issues at stake. (E.g. Allen, 2020, pp. 100, 110).
} 
By shifting the decision power partly to consumers, the Psagot judgment may trigger another sphere of dialogue with Israel, held by the civil society, added to that held by decision-makers. It may further contribute to the internal EU dialogue between topdown and bottom-up players (e.g., Berkhout et al, 2018). It suggests measurable, broader scale "objective" indication to consumers' opinion (bottom-up), which may help EU's decision-makers in designing future policy (top-down) towards the territories, according to the formers' expectations.

The success of the "power of local" or bottom-up strategy depends on the visibility of normative fiats (Gorson, 2002), including the resistance emerging 'from the local arena upon which the EU wishes to impose its normative stance' (Gordon and Pardo, 2015). In the Psagot case, visibility is obtained in four dimensions: in the judgment itself; in the Israeli political and public resistance (e.g., Eichner, 2020); in the labelling, a constant reminder of this issue to any potential consumer in the EU; and in the "tailwind" the judgment gives to future actions by European civil society actors, willing to resist Israel's control of the territories. The success of top-down and/or bottom-up normative power interference to achieve political goals depends on its broadly recognized legitimacy and credibility. Psagot's bottom-up approach builds on a strong anchor of global legitimacy credibility: consumer ethics.

Ethics seems to be a vital component of the "ideal type" perception of normative power, although the concept of the 'ethical power' of the EU is still not well developed (Kienzle, 2014). Globally, labelling claims are often made in the context of ethical criteria, such as sustainability, environmental protection, animal welfare, or labour conditions (Vergano, 2019). However, Psagot's approach builds on a broader phenomenon: the gradually changing social expectations of business corporations, beginning in the late 1990s, and the increasing recurring demands of post-materialist Western consumers that corporate business decisions will consider non-economic considerations, including ethics and human rights issues. NGOs and social movements, operating transnationally (known as the "Global Civil society") invoke these demands. They enjoy social trust and standing, enabling them to determine the ethical standards expected from corporations. The internet and social networks equip these organizations with unprecedented oversight, enabling quick, inexpensive, and substantial exposure to controversial corporate practices. This reality forces business leaders to consider broader public concerns regarding their companies' negative social externalities and address the "courts of public opinion" rather than merely the profit bottom line. ${ }^{7}$

However, the EU's material position seems to suffer some severe weaknesses in uniform position, legitimacy, consistency, and narrative. Such imperfections could undermine the international players' and the public's support the EU anticipates.

\section{Uniform Position: Speaking in One Voice}

Davis Cross (2013, 2-3) writes that the EU 'continually under performs when it comes to soft power' as a result of its weak and often negative external image. The EU is more robust when it can present a united front. Unfortunately, this is not always the case (Toje, 2008, 126-7).

Since the beginning of the dispute between Israel and the EU regarding the territories, the EU has by and large succeeded in maintaining an external united front (despite

${ }^{7}$ For further discussion see Sitbon, 2020. 
internal nuances) (Wojnarowicz and Zaręba, 2020) and a uniform position. Legally, the Psagot judgment reinforces this uniformity by determining a uniformly binding legal interpretation to EU Regulation 1169/2011. However, politically some EU members expressed their dissatisfaction with mandatory labelling of territories' products. $^{8}$

\section{Legitimacy: Does the EU Protect Universally Agreed Norms?}

Inclusiveness and legitimacy may be obtained by disseminating norms which are broadly recognized as "good" (Kienzle, 2014), or "cosmopolitan" norms (Beck, 2003). The CJEU tries to establish such legitimacy in the Brita and Psagot judgments, relying on international law (Forsberg, 2011). However, '[t]here is always a risk that actors will follow their interests even if they know that this may harm others' (Sjursen, 2006). Moreover, the most powerful are suspected for using a "moral" foreign policy for their interest, even when they don't (Eriksen, 2003). Deviating from the ethical ideal-type of cosmopolitan normative power, De Zutter (2010) suggests that the norms diffused by a normative power are not, by definition, universal. She stresses that the universality of norms depends, among other things, on their implementation, on the historical context, and on the ongoing global debates at the time of their diffusion.

In cases where there is no international agreement on a norm's essence, a question arises whether the EU is capable of, and entitled to, shaping the concept of what is "normal" in this regard. Those who answer negatively may see the EU's normative power exercise as a simple expression of Eurocentric cultural imperialism (Sejurn, 2006).

Article 31(1)(c) of the Vienna Convention on the Law of Treaties, 1969, entitled 'General rule of interpretation,' provides that to interpret a treaty such as the EU-Israel Association Agreement, 'any relevant rules of international law applicable in the relations between the parties' shall be taken into account, together with the context. The Psagot judgment relies on what the EU portrays as universal norms supported by UN and ICJ decisions. ${ }^{9}$ In this sense, it continues a line of reasoning used in Venice Declaration and the Brita judgment. ${ }^{10}$ Does the CJEU imply that these non-mandatory decisions and declarations, accepted in a highly political context, create or reflect 'rules' in the sense of Art. 31 of the Vienna Convention ${ }^{11}$, or alternatively could this reference be interpreted as implying a new customary law rule? Under the current circumstances, such implications are far-reaching. Failure to establish both these legal assumptions may undermine the entire legal basis for the EU's position.

\footnotetext{
${ }^{8}$ Greece and Germany expressed such opinions in 2015 (Weinreb, 2015 ). Czechia, Hungary, Lithuania and the Netherlands - later. (Ahren, 2019).

${ }_{9}$ See decisions specified in the CJEU judgment, para. 53 and AG Hogan's opinion footnote 26.

${ }^{10}$ Art. 3 of Venice Declaration (EU Commission, 1980, Art. 3) specifies the UN documents on which it relies as justification.

${ }^{11}$ In Brita the CJEU (para. 56) provides: 'a settlement established in breach of the rules of international humanitarian law may be the subject of ethical assessments capable of influencing consumers' purchasing decisions, particularly since some of those rules constitute fundamental rules of international law (Advisory Opinion of the International Court of Justice of 9 July 2004, Legal Consequences of the Construction of a Wall in the Occupied Palestinian Territory, ICJ Reports 2004, p. 136, paragraphs 155 to 159).' [Emphasis added]. The rules cited in this Opinion establish the right for self determination. However, the interpretative assessment that follows, implying that the Israeli treatment of the territories breaches this right is of an advisory, not mandatory status. See also footnote 26 of this opinion.
} 


\section{Consistent Application}

In reality, the CJEU's interpretation of these norms, or their application to the territories, is not necessarily accepted as universal, even by the EU itself. While the EU's policy towards the territories is justified, among other things, on the grounds of public international law alleged infringement, the EU does not seem to apply the same approach towards some 150 other territories, which are suffering a disputed public international law status, some within the EU (e.g., North Cyprus, Ceuta, and Melilla) (The Jerusalem Center, 2020). ${ }^{12}$ Lack of inclusiveness and coherence could undermine the legitimacy and reliability of the EU's approach, both internationally ${ }^{13}$ and locally.

\section{Narrative}

Nye (2009, 161) writes: 'In today's information age, success is the result not merely of whose army wins but also of whose story wins.' Convincingness depends, to a great extent, on the narrative. Narratives are the stories of 'the temporal character of human experience' (Ricoeur, 1984, 52) communicated in different ways, including the popular media, outreach programs, etc. (Ociepka, 2013). In many cases, narratives underline norms' essence and help to establish their public legitimacy.

The ongoing Israel-EU dispute over the international status of the territories reflects a clash of political views, a conflict of narratives. The Psagot judgment, its coverage in the media, and its practical effect, partly shifting the decision to the "power of local" may determine whose story will win in the medium and long run. It may demonstrate the cruciality of the foreign public's perceptions of determining state behaviour and outcomes in international relations (Davis Cross, 2013, 5).

The clash between the parties' stories reflects the differences in their international and local interests, but also their desired global statuses, backed by their stories: the Palestinian narrative portrays them as victims, deprived of their land and independence, with Israel described as a settler-colonial state. It aims to draw global support to their territorial and political claim and set forth an independent state. The EU's narrative focuses on supporting its desired international image as a global player: A global guardian of public international law rules and fundamental rights of the Palestinians, while simultaneously recognizing the legitimate Israeli concerns.

In recent decades, right-wing Israeli leaders face intense domestic pressure to continue their current hawkish policy regarding the territories. This internal political need collides with Israel's desired external image as an advocate of international law rules, respecting globally recognized fundamental rights and values. As a small country situated in an unfriendly neighbourhood, Israel depends on global, economic, and political support, particularly from the US, its major political ally, and the EU, its major trade partner. Obtaining this support depends on maintaining a positive external image.

${ }^{12}$ CJEU's approach to the concept of 'territory' in international law was criticized (Cardwell and Wessel, 2020, pp. 21-23; Kanevskaia, 2020). Kuchenbecker and Tucker (2019) suggest that 'if EU law would be interpreted as requiring that all perceived violations of international law must be addressed by product labeling, it would be a vastly complex commercial disaster.'

13 The United States, for example, found this decision biased against Israel. (Schneider, 2019). 
Torn between these two conflicting narratives, Israel is well aware of the narrative's importance and the importance of its global acceptance. Thus, Israel invests energy in explaining that its presence in the territories is compatible with these globally agreed values and rules externally. ${ }^{14}$ The EU's narrative, substantially supporting the Palestinian narrative, competes with the Israeli narrative to gain the global public's support.

Reeves (2004) differentiates between the narrative and the plot, contending that the plot is visible while the narrative is hidden. In the Brita and Psagot cases, the wording of the legal norms at stake allows for conflicting interpretations. The legal, allegedly "technical" reasoning - the "plot" - focuses on consumer protection in Psagot and on rules of origin in Brita. In both judgments, the CJEU opts for the "plot" serving the EU narrative and its political goals.

While politicians and courts may consciously use narratives as leverages to promote agendas, individuals may be strongly affected by them to change their behaviour. In this sense, the EU's approach towards the territories may encourage a civil agenda which will reinforce EU members' cohesion (Keohane, 2002). Naomi Klein (1999) demonstrated in her classical book No Logo that narratives play an essential role in a commercial context, as corporations conceal the poor production conditions of wellknown brands, while civil society organizations strive to expose these conditions to raise consumers' awareness and trigger (market) pressure on the corporations to change their behaviour.

Partisans of Israel's boycotting, mainly among the Boycott, Divest, Sanction movement (BDS) campaign activists, often evoke the commercial boycott of South Africa, which was an essential factor leading to the collapse of Apartheid, as a model of economic pressure that could encourage Israeli withdrawal from the territories. In Psagot, Advocate General Hogan explicitly adopts this analogy, integrating it with the official EU narrative, directly addressing consumers (CJEU, 2019, para. 51).

The similarities drawn between Israel's control of the West Bank and Apartheid in South Africa include application of different laws for Israeli settlers and Palestinians and other terms of access to water and roads. ${ }^{15}$ Nonetheless, there are essential flaws in this comparison, which AG Hogan ignored, perhaps because they could undermine this comparison and thus harm the EU's narrative:

- The historical context of the dispute (e.g., Kuchenbecker and Tucker, 2019, 5-6) implies a different international status for each of the "territories".

- Legitimate Israeli security concerns due to ongoing Palestinian hostilities made Israel stop the territories' withdrawal according to the 1993 and 1995 Oslo Agreements;

- The Palestinian Authority effectively controls the daily lives of $98 \%$ of Palestinians living in the West Bank;

- Israel is singled out although the gravity of its practices is immeasurably smaller than many other occupying countries.

\footnotetext{
14 For example, the Levy Commission Report on the Legal Status of Building in Judea and Samaria (Levy 2012) established the legality of Israeli settlements in Judea and Samaria according to public international law.

${ }^{15}$ See e.g. the different reports in the B'tselem website - https://www.btselem.org/publications.
} 
These differences may explain the CJEU judges' refrainment from explicitly mentioning the comparison to South African Apartheid in the Psagot judgment. However, one can never know to what extent AG Hogan's use of this analogy substantially inspired their final decision. Brita's legal discourse and AG Hogan's analysis in Psagot, can enhance and strengthen this inaccurate analogy among consumer activists. In the end, it is all about "framing" (Lakoff et al., 2004), i.e., the persuasive use of political metaphors.

\section{Assessment of Potential Impact}

Cross Davis $(2013,5)$ notes the mutual feedback between the external audience's positive approach towards the diffused norms and the diffusing government. If this assessment is correct, a positive national and international response to the labelling of products originating in the territories may encourage this EU policy.

Baum and Potter (2019) believe that social media erodes the democratic publics' ability to constrain foreign policy by making it harder for citizens to informationally "catch up." In the Psagot judgment, the CJEU created an ongoing robust reminding mechanism, inviting consumers to reflect on the territories dispute and take a stand regarding the narrative with every product's choice.

Manners (2002, 242, 244) identifies five "core" EU norms: peace, liberty, democracy, the rule of law, and respect of human rights. Their reinforcement and expansion 'allows the EU to present and legitimate itself as being more than the sum of its parts.' [Original emphasis]. According to the EU, Israel's presence in the territories challenges all these norms. The EU's current policy continuation thus runs down to the core of its raison d'etre. Hitherto the EU has restricted its policy primarily to the declarative sphere: the CJEU ensures that the EU's international image would not imply its pragmatic international responsibility (Hommelbrunner, 2019, 787), leaving to its leaders the necessary flexibility and discretion. ${ }^{16}$ These may be affected by global and local public opinion.

In the meantime, the Psagot judgment's approach is not necessarily acceptable to a broad range of other countries, particularly the US. ${ }^{17}$

Narratives, positions, and perceptions change over time. ${ }^{18}$ Interpretation of the rules of origin for products originating in the territories according to EU-Israel trade agreements changed over time ${ }^{19}$. It might change again in the future if reality - or the EU's political position - changes. ${ }^{20}$ Israel's recent peace agreements with some Muslim

\footnotetext{
${ }^{16}$ See, e.g., discussion on stricter options of interpretation to international law in this context. (Ryngaert, 2019). 17 The US criticized it as creating an 'anti-Israel bias'. (Ortagus, 2019) Decision makers in the US assessed that this EU position could have negative implications on US-EU trade relations. (San Diego Jewish World, 2019). ${ }^{18}$ US's President Donald Trump considerably changed US's position to support Israel's position regarding the ongoing regional conflict, compared to his predecessors.

${ }^{19}$ From 1975 to mid-1990's the West Bank, the Golan Heights, East Jerusalem and the Gaza Strip, before Israel withdrew it, enjoyed the benefits of Israel-EU Free Trade Area agreement without reservation of the Palestinian people or of the EU. This interpretation served the Palestinian economic interest, and the EU's political interest. The conclusion of EU-PLO Association Agreement (EU, 1997), created for the Palestinians a legal alternative conduit, through which their exported products to the EU could enjoy trade benefits, allowing them to replace their pragmatic, approach with a politically challenging approach, supported by the EU.

${ }^{20}$ De Zutter (2010) indicates that the dynamism of EU norms undermines any search for any fixed and eternal set of norms for a normative power.
} 
states (the UAE, Bahrein, Morocco, Sudan) may encourage such a change in the long run.

However, more Psagot-like decisions may carry a psychological impact on European public opinion, which is more mindful of the human rights discourse. It may even bolster the so-called "Silent Boycott" - the resolution of more and more businesses in the EU to "have no dealings" with Israel, without publicly voicing an opinion (Koren, 2015). The small Israeli market, highly dependent on imports and exports, forming almost $60 \%$ of its GDP (Israeli Central Bureau of Statistics, 2020), and on foreign investments, may be Israel's 'Achilles' Hill. ${ }^{21}$ (Kofman, 2014). Other sectors, such as Israeli academia, heavily dependent on Israel-EU cooperation agreements, might also be affected.

\section{Conclusion}

The fall of the Iron Curtain in 1989 triggered the development and application of the soft power theory, which closely links with globalization. Some believe that soft power loses its strength in the current reality, where countries withdraw back into nationalism (Li, 2018). The Psagot judgment proves that it may be too early to rule out the effect of soft power, despite the drawbacks of the EU's strategy, noted above. The combination of normative power and bottom-up local power may change the game rules, potentially adversely affecting European politicians' and corporations' approaches towards Israel.

While it seems unlikely that this new combination of power will change Israel's position towards the territories, it burdens the Israeli campaign: in addition to convincing decision-makers, through legal and political discourse, Israel has to convince public opinion. The battlefield may now move to social networks or the streets and stores. If, in the medium and long term, the Palestinians'/EU's narrative achieves a broader global effect, Israel may be forced to reconsider its strategy, to avoid severe economic and political damage. Such a shift in Israel's position would mark the success of the EU's soft power approach.

\section{References}

Ahren, R. (2019). On Labelling Settlement Goods, the European Union is Far From United. The Times of Israel, 2 December https://www.timesofisrael.com/on-labelingsettlement-goods-the-european-union-is-far-from-united.

Allen, S. (2020). Direct Challenges to EU Measures Adopting Trade Agreements: Locus Standi and the Front Polisario's Western Sahara Claims in the EU Courts. In: E. Kassoti \& R. Wessel (eds.) EU Trade Agreements and the Duty to Respect Human Rights Abroad. (CLEER Papers 2020/1, 95-111) https://www.asser.nl/media/679745/cleero20-01_web_final.pdf.

Babic, M., Fichtner, J. \& Heemskerk, E.M. (2017). States versus Corporations: Rethinking the Power of Business in International Politics. The International Spectator: Italian Journal of International Affairs 52(4), 20-43.

\footnotetext{
${ }^{21}$ The RAND Corporation estimated potential economic damages of the BDS campaign to the Israeli economy at
} 15 billion US dollars (RAND Institute, 2015). 
Baum M. \& Potter, P. (2019). Media, Public Opinion, and Foreign Policy in the Age of Social Media. The Journal of Politics 81(2), 747-756.

Beck, U. (2003). Kosmopolitische globalisierung: die schöpferische selbstzerstörung der Weltordnung. Internationale Politik, 58(7), 9-13.

Berkhout, J., Beyers, J., Braun, C., Hanegraaff, M. \& Lowery, D. (2018). Making Inference across Mobilisation and Influence Research: Comparing Top-Down and Bottom-Up Mapping of Interest Systems. Political Studies 66(1), 43-62.

CJEU (2010). C-386/o8 Brita GmbH v. Hauptzollamt Hamburg-Hafen 2010 ECJ EUR-Lex LEXIS 63 (25 February 2010).

CJEU (2019). Case C-363/18 Organization juive Europeenne, Vignoble Psagot LTD v. Ministre de l'Economie et des Finances. Judgment:

http://curia.europa.eu/juris/liste.jsf?num=C-363/l; Opinion of AG Hogan:

http://curia.europa.eu/juris/document/document.jsf;jsessionid=D9F5005 $\mathrm{C}_{5} \mathrm{E} 2 \mathrm{C} 6 \mathrm{D}$ 7FE0897BE826008DoA?text $=\& d o c i d=214961 \&$ pageIndex $=0 \&$ doclang $=$ en\&mode $=\mathrm{ls}$ $\underline{t} \& \operatorname{dir}=\& o c c=$ first $\&$ part $=1 \&$ cid $=9082288$.

Davis Cross, M. (2013). Conceptualizing European Public Diplomacy. In M. Davis Cross \& J. Melissen (eds.), European Public Diplomacy: Soft Power at Work (1st ed) (1-12). New York, NY: Palgrave Macmillan.

Del Sarto, R. (2016). "Normative Empire Europe: The European Union, its borderlands, and the 'Arab Spring', 54 JCMS pp. 215-232.

De Witte, B., Mayoral, J., Jaremba, U., Wind M. \& Podstawa, K. (eds.) (2016). National Courts and EU Law. Cheltenham: Edward Elgar Publishing.

De Zutter, E. (2010). Normative Power Spotting: on Onthological and Methodological Appraisal. Journal of European Public Policy, 17(8), 1106-1127.

Diez, T. (2013). Normative Power as Hegemony. Cooperation and Conflict, 48(2), 194-210.

Duchêne, F. (1972). Europe's Role in World Peace. In: R. Mayne. Europe Tomorrow: Sixteen Europeans Look Ahead (pp. 32-47). London: Fontana.

Duchêne, F. (1973). The European Community and the Uncertainties of Interdependence. In M. Kohnstamm \& W. Hager (eds.), A Nation Writ Large? Foreign Policy Problems before the European Community. Basingstoke: Macmillan.

Eriksen, E. O. (2003). Why a constitutionalised Bill of Rights? In The Chartering of Europe, Edited by: Eriksen, E. O., Fossum, J. E. and Ménendez, A. J., 48-70. BadenBaden: Nomos.

European Council (1980). Venice Declaration of 13 June 1980. http://www.eeas.europa.eu/archives/docs/mepp/docs/venice declaration 1980 en. pdf

European Union (2011). Regulation (EU) no. 1169/2011 of the European Parliament and the Council of 25 October 2011 on the provision of food information to consumers, amending Regulations (EC) No 1924/2006 and (EC) No 1925/2006 of the European Parliament and of the Council, and repealing Commission Directive 87/250/EEC, Council Directive 90/496/EEC, Commission Directive 1999/10/EC, Directive 2000/13/EC of the European Parliament and of the Council, Commission Directives 2002/67/EC and 2008/5/EC and Commission Regulation (EC) No 608/2004 Text 
with EEA relevance, OJ L 304, 22.11.2011, 18-6. https://eur-lex.europa.eu/legalcontent/EN/ALL/?uri=CELEX\%3A32011R1169

European Union (1997). Euro-Mediterranean Interim Association Agreement on trade and cooperation between the European Community, of the one part, and the Palestine Liberation Organization (PLO) for the benefit of the Palestinian Authority of the West Bank and the Gaza Strip, of the other part, OJ L 187/3, 16.7.1997.

European Union (2000). Euro-Mediterranean Agreement establishing an association between the European Communities and their Member States, of the one part, and the State of Israel, of the other part, OJ L 147/3 21.6.2000.

https://library.euneighbours.eu/content/eu-israel-association-agreement

Forsberg, T. (2009). Normative power Europe (once more): a conceptual clarification and empirical analysis. annual convention of the International Studies Association, New York, 15-18 February.

Forsberg, T. (2011) Normative power Europe, once again: a conceptual analysis of an ideal type, Journal of Common Market Studies, 49(6), pp. 1183-1204.

Galtung, J. (1973). The European Community: A Superpower in the Making. London: Allen \& Unwin.

Gordon, N. (2002). On Visibility and Power: An Arendtian Corrective of Foucault. Human Studies 25(2), 125-145.

Gordon, N. \& Pardo, S. (2015). Normative Power Europe and the Power of the Local. Journal of Common Market Studies 52(2), 416-427.

Hill, C. (1993). The Capability-Expectations Gap, or Conceptualizing Europe's International Role. Journal of Common Market Studies 31(3), 305-328.

Hommelbrunner, S. (2019). Contextualization of Psagot in light of Other CJEU Case Law on Occupied Territories, European Papers 4(3), 779-789.

Hopf, T. (1998). The promise of constructivism in international relations theory. International Security, 23(1), 171-200.

Israeli Central Bureau of Statistics (CBS). Table D. 4 - Imports and Exports, by Commodity Groups - Total E.U. https://old.cbs.gov.il/www/fr trade/d4t2.pdf

Kanevskaia Whitaker, O. (2020). Misinterpreting Mislabeling: the Psagot Ruling, European Papers 4, 763.

https://www.researchgate.net/publication/339984696 Misinterpreting Mislabellin g The Psagot Ruling

Keohane, R. O. (2002). Ironies of sovereignty: the European Union and the United States. Journal of Common Market Studies, 40(4), 74--65.

Kienzle, B. (2014). The New Face of EU Security Policies? Analysing the Normative Patterns of EU Non-Proliferation Policies in the Southern Mediterranean. Mediterranean Politics, 19(1), 40-58.

Klein, N. (1999). No Logo: Taking Aim at the Brand Bullies. Toronto: Knopf Canada \& Picador.

Kofman, E. (2014). Analysis of potential implication of an economic boycott on Israel. The Knesset's Center for Information and Research [Hebrew] 
https://fs.knesset.gov.il/globaldocs/MMM/ff4e6b58-egf7-e411-8oc800155d010977/2_ff4e6b58-egf7-e411-80c8-00155d010977_11_10368.pdf

Koren, O. (2015). Ministry of Economics VP Foreign Trade: Silent boycott More Harmful Than BDS Campaign. The Marker 27.11.2015 [Hebrew] www.themarker.com/news/macro/1.2786293

Kuchenbecker, G. \& Tucker, A. (2019). The Israeli Products Labelling Controversy Imposing Politically-motivated Opinions in the Name of Law An analysis of the AG's Opinion in the Psagot Winery Case. https://www.thinc.info/wpcontent/uploads/2019/08/Psagot-winery-final 20190726ocx.pdf

Lakoff, G., Dean, H. \& Hazen, D. (2004). Don't Think of an Elephant! Know Your Values and Frame the Debate. Chelsea: Chelsea Green Publishing.

Levy, A. (2012). The Levy Commission Report on the Legal Status of Building in Judea and Samaria https://israelipalestinian.procon.org/sourcefiles/The-Levy-CommissionReport-on-the-Legal-Status-of-Building-in-Judea-and-Samaria.pdf

Li, E. (2018). The Rise and Fall of Soft Power. Foreign Policy 20 August http://foreignpolicy.com/2018/08/20/the-rise-and-fall-of-soft-power/

Manners, I. (2002). Normative Power Europe: A Contradiction in Terms? Journal of Common Market Studies, 40(2), 235-258.

Maull, H. W. (2005). Europe and the new balance of global order. International Affairs, 81(4): 775-99.

Menon, A., Nicolaïdis, K. and Walsh, J. (2004). In defence of Europe - a response to Kagan. Journal of European Affairs, 2(3), 5-14.

Munin, N. (2011). Can Customs Rules Solve Difficulties Created by Public International Law? Thoughts on the ECJ's Judgment in Brita Case (C-386/o8). Global Trade and Customs Journal, 6(4), 193-207.

Munin, N. (2013). EU Measures Towards Israeli Activities in the Occupied Territories and the BDS: A Diplomatic Achievement or a Pyrrhic Victory? Journal of Multidisciplinary Research 7(3), 55-73.

Nye, J.S. (1990). Bound to Lead: The Changing Nature of American Power. Art of Mentoring Series (reprint ed.). London: Basic Books.

Nye, J.S. (2004). Soft Power: The Means to Success in World Politics (1st ed.). New York: Public Affairs.

Nye, J.S. (2009). Get Smart: Combining Hard and Soft Power. Foreign Affairs 88(4), 160163.

Ociepka, B. (2013). New Members' Public Diplomacy. In M. Davis Cross, \& J. Melissen (eds.) European Public Diplomacy: Soft Power at Work (1st ed) (pp. 39-56) New York: Palgrave Macmillan.

Oliviera, M. (2015). International Trade Agreements Before Domestic Courts: Lessons From the EU and Brazilian Experiences. Cham: Springer.

Ortagus, M. (2019). Decision by EU Court of Justice on Psagot Case: Press statement by US department of State's spokesman, 13 November https://www.state.gov/decision-byeu-court-of-justice-on-psagot-case/ 
Pace, M. (2009). Paradoxes and contradictions in EU democracy promotion in the Mediterranean: the limits of EU normative power. Democratization, 16(1), 39-58.

Pace, M. (2010) The European Union, security and the southern dimension, European Security, 19(3), 431-444.

Pardo S. and Zemer L. (2011). Bilateralism and the Politics of European Judicial Desire, The Columbia Journal of European Law, Vol. 17(2): 263-305.

Poletti, A. \& Sicurelli, D. (2018). The Political Economy of Normative Trade Power Europe. London: Palgrave Macmillan.

RAND Institute (2015). The Costs of the Israeli-Palestinian Conflict www.rand.org/content/dam/rand/pubs/research reports/RR70o/RR7401/RAND_RR740-1.pdf.

Reeves, J. (2004). Culture and International Relations: Narratives, Natives and Tourists. London and New York: Routledge.

Ricoeur, P. (1984). Time and Narrative (translated by K. McLaughlin, and D. Pellauer) Chicago: University of Chicago Press.

Rosecrance, R. (1998). The European Union: A New Type of International Actor. In J. Zielonka (ed.) Paradoxes of European Foreign Policy (pp. 15-23). The Hague: Kluwer Law International.

Ryngaert, C. (2019). Indications of Settlements Provenance and the Duty of Non-Recognition Under International Law. European Papers, 4(3), 791-799.

San Diego Jewish World (2019). EU Court Mandates Labeling of Israeli Products (12 November). https://www.sdjewishworld.com/2019/11/12/eu-court-mandateslabeling-of-israeli-products/

Schneider, T. (2019). US's State Department: Very Concerned about CJEU Decision. Globes 13.11.19 [Hebrew] https://www.globes.co.il/news/article.aspx?did=1001307159

Sitbon, O. (2020). Human Rights, Normative Pressure and Corporate Social Responsibility

in the Israeli-Palestinian Conflict. Georgetown Journal of International Law, 52, 215-261.

Sjursen, H. (2006). The EU as a 'Normative' Power: How Can This Be? Journal of European Public Policy, 13(2), 235-251.

Smith, K. (2000). The end of civilian power EU: A welcome demise or cause for concern? The International Spectator: Italian Journal of International Affairs 23(2), 11-28.

Smith, M. (2006). Soft Power Rising: Romantic Europe in the Service of Practical Europe. World Literature Today 80(1), 20-23.

Strange, S. (1991). Big Business and the State. Millennium Journal of International Studies $20(2), 245-250$.

Toje, A. (2008). The Consensus-Expectations Gap: Explaining Europe's Ineffective Foreign Policy. Security Dialogue 39(1), 121-141.

The Jerusalem Center (2020). Is the EU Deploying a Double Standard Towards Israel? https://www.youtube.com/watch?v=GBsEm-KJKug 
Vergano, F. (2019). An Advocate General of the Court of Justice of the EU holds that the origin of Israeli settlement goods should be indicated - legal issues surrounding "ethical considerations" in food law. Trade Perspectives 13, 28 June http://www.fratinivergano.eu/en/issue-number-13-28-june2019/\# An Advocate General

Weinreb, Y. (2015). The Greek Minister of Foreign Affairs does not Approve of Labelling Products Originating in Israeli Settlements. Rotter, 16 April [Hebrew].

Whitman, R. (2011). Norms, Power and Europe: A New Agenda for Study of the EU and International Relations in R. Whitman. Normative Power Europe: Empirical and Theoretical Perspectives, 1-22. London: Palgrave Macmillan.

Wojnarowicz, M. \& Zaręba, S. (2020). Court of Justice of the EU Ruling on Products from Territories Occupied by Israel. Polski Instytut Spraw Międzynarodowych (PISM) Bulletin, Central and Eastern European Library (CEEOL) https://www.ceeol.com/search/gray-literature-detail?id=847106 